\title{
Akseptabilitas Orang Tua Terhadap Anak Berkebutuhan Khusus di Kota Yogyakarta (Studi Kasus Pada Lembaga Federasi Komunikasi Keluarga Penyandang Disabilitas)
}

\author{
Erlita Normasari ${ }^{1}$, Meita Fitrianawati ${ }^{2}$, dan Nurul Hidayati Rofiah ${ }^{3}$ \\ 1,2,3 Universitas Ahmad Dahlan, Yogyakarta, Indonesia. \\ Email: erlitans@gmail.com
}

\section{Info Artikel}

Sejarah Artikel:

Diserahkan 19 Agustus 2021

Direvisi 18 Oktober 2021

Disetujui 25 Oktober 2021

Keywords:

Parental acceptance

Special need children

Disability

\section{Abstract}

This study aims to determine the stages of acceptability, acceptability aspects, and acceptability factors of parents to children with special needs in the city of Yogyakarta.

The subjects of this study were parents and families of children with special needs. Subject selection using purposive sampling. The object of the research is the acceptability of parents who have special needs and are members of the Federation of Family Communities with Disabilities (FKKPD). This research is a qualitative research with collection techniques through interviews and documentation, data credibility test using reference materials, and interactive model data analysis techniques (data collection, data reduction, data presentation, and drawing conclusions).

The results showed that parents had reached the stage of acceptability (accepting) their children with special needs, by going through several stages of denial (denial), anger (anger), bargaining (bargaining), depression (depression) and acceptance (acceptance). This can be seen from the acceptance aspects and is supported by the acceptance factors of parents. However, there is one parent who does not accept their child with special needs.

\footnotetext{
Abstrak

Penelitian ini bertujuan untuk mengetahui tahapan akseptabilitas, aspek-aspek akseptabilitas, dan faktor-faktor akseptabilitas orang tua terhadap anak berkebutuhan khusus di Kota Yogyakarta.

Subjek penelitian ini adalah orang tua dan keluarga dari anak berkebutuhan khusus. Pemilihan subjek menggunakan purposive sampling. Objek penelitian adalah akseptabilitas orang tua yang memiliki ABK dan tergabung dalam lembaga Federasi Komunitas Keluarga Penyandang Disabilitas (FKKPD). Penelitian ini merupakan penelitian kualitatif dengan teknik pengumpulan melalui wawancara dan dokumentasi, uji kredibilitas data menggunakan bahan referensi, serta teknik analisis data model interaktif (pengumpulan data, reduksi data, penyajian data, dan penarikan kesimpulan).

Hasil penelitian menunjukkan bahwa orang tua telah sampai tahap akseptabilitas (menerima) anaknya berkebutuhan khusus, dengan melalui beberapa tahap dari penolakan (denial), marah (anger), tawar-menawar (bargaining), depresi (depression) dan tahap penerimaan (acceptance). Hal tersebut terlihat dari aspek-aspek penerimaan dan di dukung oleh faktor-faktor penerimaan orang tua. Namun ada satu orang tua yang tidak menerima anaknya berkebutuhan khusus.
} 


\section{PENDAHULUAN}

Anak berkebutuhan khusus atau disingkat dengan ABK dan bisa disebut juga disabilitas merupakan anak yang menyimpang dari rata-rata anak normal, baik menyimpang ke atas maupun ke bawah dari kriteria normal dalam hal karakteristik mental, kemampuan sensoris, karakteristik neumotor atau fisik, perilaku sosial serta emosional, kemampuan berkomunikasi, maupun gabungan dari berbagai variabel tersebut sejauh ia memerlukan modifikasi pelaksanaan sekolah dalam bentuk pelayanan pendidikan khusus (special need education), untuk mengembangkan kapasitasnya secara maksimum (Marlina, 2009). ABK sebagai anak yang memiliki kemampuan berbeda dengan temanteman lainnya (Ardianti dkk, 2021). Salah satu peran penting orang tua adalah pemenuhan kebutuhan ABK salah satunya adalah hak memperoleh pendidikan, baik pendidikan inklusif ataupun pendidikan khusus. Peran orang tua dalam menemani proses kehidupan anak berkebutuhan khusus bukanlah hal yang mudah. Akseptabilitas orang tua menjadi kunci utama langkah awal dalam membersamai tumbuh kembang anak agar lebih optimal. Akseptabilitas merupakan kata serapan dari acceptance yang mempunyai arti penerimaan.

Menurut (Pancawati, 2013:40) penerimaan awal orang tua biasanya menunjukkan sikap stres, kecewa, patah semangat, mencari pengobatan kemana-mana, serba khawatir terhadap masa depan anaknya dan lain-lain, untuk dan mencapai penerimaan harus melewati beberapa tahap. Data yang dihimpun dari Terpadu Penanganan Fakir Miskin (PPFM) individu penyandang cacat pada tahun 2015 mencapai 320 ribu jiwa. Kemudian berdsarkan data dari BPS bahwa pada tahun 2017 jumlah Anak Berkebutuhan Khusus di Indonesia mencapai angka 1,6 juta anak, dari 1,6 juta juta anak berkebutuhan khusus di Indonesia, baru $18 \%$ yang sudah mendapatkan pendidikan inklusi. Sekitar 155 ribu bersekolah di SLB, sedangkan ABK yang bersekolah di sekolah reguler pelaksana sekolah inklusi berjumlah sekitar 299 ribu. Angka tersebut masih belum sebanding dengan pemenuhan hak anak-anak berkebutuhan khusus terutama pada bidang kesehatan, pendidikan, serta fasilitas umum bagi anak-anak berkeutuhan khusus. Data di atas merupakan salah masalah yang dihadapi para orang tua dalam pemenuhan hak mendapatkan pendidikan bagi anak berkebutuhan khusus (Maulipaksi, 2017).

Pada saat pembukaan Lomba Pendidikan Khusus Layanan Khusus (PKLK) tanggal 3 Agustus 2018, kepala Dinas Pendidikan DIY
Kadarmanta Baskara Aji dalam (Syarifudin, 2018) menyampaikan bahwa ada seribu ABK yang belum mendapatkan hak pendidikan. Mereka belum masuk sekolah inklusi maupun SLB. Alasan merka belum mendapatkan hak pendidikan juga beragam, karena orang tua terlalu sibuk bekerja sehingga tidak ada waktu untuk mengantarkan kesekolah, jarak sekolah yang terlalu jauh, dan tidak memiliki biaya. Selain itu, orang tua juga merasa malu jika anaknya yang berkebutuhan khusus keluar rumah. Hal tersebut menjadikan sebuah keprihatinan bersama bahwa ada hak-hak ABK yang belum terpenuhi. Amanat dari UU Sisdiknas tahun 2003 Bab IV pasal 5 juga sudah jelas, bahwa warga negara yang memiliki kelainan fisik, emosional, mental, intelektual, dan/atau sosial berhak memperoleh pendidikan khusus.

Untuk menghimpun orang tua yang memiliki anak berkebutuhan khusus, dibentuklah sebuah lembaga Federasi Komunitas Keluarga Penyandang Disabilitas (FKKPD) di Kota Yogyakarta. Wawancara yang dilakukan kepada ketua pengelola FKKPD memaparkan bahwa orang tua yang memiliki ABK di Kota Yogyakarta masih minim wawasan mengenai pemberdayaan diri untuk sebagai bekal orang tua dalam mengembangkan potensi anak berkebutuhan khusus. Kendala waktu orang tua untuk mengantarkan anaknya mengikuti kegiatan yang diselenggarakan lembaga juga menjadi permasalahan. Selain itu, kurang percayanya orang tua terhadap potensi yang dimiliki oleh anak, sehingga sikap percaya diri sulit muncul pada diri anak.

Penelitian ini bertujuan untuk mengetahui akseptabilitas orang tua yang memiliki ABK dan untuk mengetahui upaya orang tua dalam meningkatkan perkembangan Anak Berkebutuhan Khusus pada Lembaga Federasi Komunitas Keluarga Penyandang Disabilitas (FKKPD) di Kota Yogyakarta. Hal ini dikarenakan menurut Hurlock dalam (Devina, 2016:45) seseorang dikatakan mampu melakukan penerimaan diri apabila menunjukkan respon yang tepat saat mengatasi tekanan hidupnya. Semakin baik seseorang dalam menerima diri nya dapat berdampak pada penyesuaian diri dan penyesuaian sosialnya.Berdasarkan uraian diatas peneliti mengambil judul "Akseptabilitas Orang Tua Pada Anak Berkebutuhan Khusus di Kota Yogyakarta (Studi Kasus Pada Lembaga Federasi Komunitas Penyandang Disabilitas)”.

\section{METODE PENELITIAN}

Metode penelitian menjelaskan rancangan Jenis penelitian dalam penelitian ini adalah 
penelitian kualitatif dan metode yang digunakan adalah studi kasus. Strategi studi kasus digunakan untuk mengungkap tentang penerimaan orang tua yang memiliki anak berkebutuhan khusus usia sekolah dasar pada Lembaga Federasi Komunitas Keluarga Penyandang Disabilitas (FKKPD) di Kota Yogyakarta secara lebih mendalam.

Subjek primer dalam penelitian ini adalah orang tua yang memiliki anak berkebutuhan khusus (ABK) tunanetra satu orang, tunarungu wicara satu orang, dan gangguan perilaku satu oarang. Sebjek sekundernya adalah keluarga. Objek penelitiannya adalah sikap penerimaan orang tua yang memiliki anak berkebutuhan khusus usia sekolah dasar pada lembaga FKKPD di Kota Yogyakarta. Dalam penelitian ini pemeriksaan keabsahan data yang digunakan peneliti yaitu menggunakan bahan referensi hasil wawancara dan foto. Serta penelitian ini menggunakan analisis data kualitatif deskriptif menurut Menurut Miles dan Huberman dalam bukunya Sugiyono (2016) yaitu (1) reduksi data, (2) penyajian data, (3) penarikan/ verifikasi kesimpulan.

\section{HASIL DAN PEMBAHASAN}

Akseptabilitas atau keberterimaan orang tua ketika memiliki anak berkebutuhan khusus dipaparkan dalam hasil wawancara mengenai tahapan penerimaan, aspek-aspek penerimaan, dan faktor-faktor penerimaan. Dalam proses penerimaan anak berkebutuhan khusus ada beberapa tahapan yang di lalui orang tua hingga akhirnya dapat menerima keberadaan anaknya yang berkebutuhan khusus.

\section{Tahapan Akseptabilitas Orang Tua}

Teori penerimaan (acceptance) Kubbler Ross dalam (Faradina, 2016:389), yakni: tahap penolakan (denial), tahap marah (anger), tahap tawar-menawar (bargainning), tahap depresi (depression) dan tahap penerimaan (acceptance). Tahapan tersebut menggambarkan proses orang tua dalam menerima anak nya yang berkebutuhan khusus. Tahap pertama adalah penolakan, sikap pertama yang ditunjukkan orang tua yaitu kaget mendapati anaknya mengalami kebutuhan khusus. Orang tua tidak percaya anaknya mengalami kebutuhan khusus karena di lingkungan keluarga tidak ada riwayat yang memiliki kebutuhan khusus, perasaan kasihan, dan diliputi rasa bersalah pada diri orang tua. Tahap kedua adalah marah (anger). Masing-masing orang tua dalam tahapan ini mengekspresikan dengan cara yang berbeda ada yang mengalami iri hati karena anak mereka memiliki kebutuhan khusus, kemudian marah terhadap diri sendiri, dan ada orang tua yang tidak menerima kondisi anak yang ditunjukkan dengan tidak diasuh langsung oleh orang tua kandungnya. Tahap kemarahan ini sangat sulit untuk diatasi dari sudut pandang keluarga. Hal tersebut seperti yang diungkapkan oleh dr. G dalam Kubler-Ross (2009) ketika tahap pertama penolakan tidak dapat dipertahankan lagi, itu digantikan oleh perasaan marah, marah, iri hati, dan dendam.

Tahap ketiga adalah tawar menawar. Indikator tawar menawar adalah orang tua meminta kesembuhan kepada Tuhan dan melakukan konsultasi ke dokter untuk kesembuhan anaknya. Orang tua berdo'a kepada Tuhan agar anaknya diberikan kesembuhan, bisa lebih mandiri, dan bisa diajak komunikasi. Harapan orang tua tidak hanya sebatas dalam untaian do'a, tetapi melakukan konsultasi dengan dokter untuk kesembuhan anaknya. Hasil pemeriksaan menyatakan masing-masing anak memiliki jenis disabilitas yang tidak hanya satu jenis dan kemungkinan untuk sembuh total tidak anak bisa.

Tahap keempat adalah depresi. Seseorang mengalami stres yang tidak dapat teratasi, ia bisa jatuh pada fase depresi. Menurut Lubis (2016) depresi adalah suatu pengalaman yang menyakitkan dan merupakan gangguan perasaan (afek) yang ditandai ditandai dengan afek disforik (kehilangan kegembiraan/gairah). Pada tahap ini, dukungan keluarga juga penting agar tidak merasa sedih yang berkepanjangan. Depresi yang dialami oleh orang tua masing-masing mempunyai alasan yang bereda-beda, contohnya adalah Depresi yang dialami orang tua ketika berada sendiri di rumah dan meratapi keadaan anak, kemudian ketika orang tua kandung dari anak tersebut tidak peduli, dan antisipasi yang dilakukan ketika depresi diekspresikan dalam bentuk emosi adalah menghentikan semua aktivitas dan fokus terhadap keinginan anak. Tahapan yang kelima adalah penerimaan (acceptance). Indikator orang tua dapat menerima anaknya yang berkebutuhan khusus menurut Hurlock dalam (Dolu, dkk. 2014) dapat dilihat dari perilaku orang tua terhadap anaknya seperti rasa sayang, kelekatan, kepedulian, dukungan, dan pengasuhan dimana orang tua tersebutbisa merasakan dan mengekspresikan rasa sayang pada anaknya. Orang tua menunjukkan sikap menerima kondisi anak salah satunya merasa lebih bersyukur karena di luar lingkungan mereka masih ada anak berkebutuhan khusus yang keadaannya lebih parah dibandingkan dengan anak nya.

\section{Aspek-aspek Akseptabilitas Orang Tua}


Indikator penerimaan orang tua terhadap anaknya yang berkebutuhan khusus adalah berpartisipasi dalam kegiatan anak, memikirkan dan berusaha untuk meningkatkan perkembangan anak, memnuhi kebutuhan secara fisik maupun psikis, menjalin komunikasi secara baik dan bijak, tidak membedakan dan membandingkan dengan anak lain, memberikan bimbingan, semangat, dan motivasi, menjadi teladan yang baik bagi anak dengan cara berkelakuan baik, dan tidak menuntut atau memaksakan kehendak anak (Hurlock, dalam Moktaningrum, 2014).

Aspek pertama penerimaan adalah berpartisipasi dalam kegiatan anak. Menurut Arifin dalam (Umar, 2015) peran orang tua adalah sebagai pengasuh/pendidik, pembimbing, motivator dan fasilitator. Masing-masing ABK memiliki kegiatan yang berbeda dan cukup beragam yaitu kegiatan di sekolah kegiatan di rumah, dan di luar rumah. Dalam perannya sebagai pengasuh, ketika anak sedang berada di sekolah anak dipercayakan oleh gurunya ini sebagai wujud mendidik anak agar mandiri. Sebagai pembimbing orang tua menemani kegiatan anak ketika melakukan sesuatu yang belum bisa anak lakukan sendiri, seperti makan, mandi, memakai baju, untuk melakukan hal tersebut masih membutuhkan kolaborasi serta bimbingan orang tua.

Aspek kedua adalah memikirkan dan berusaha untuk meningkatkan perkembangan anak. Hal tersebut dapat dilihat dari upaya orang tua untuk memenuhi kebutuhan pendidikan yaitu dengan memberikan kesempatan bagi anak untuk bersekolah. Selain itu, diikutkan dalam program terapi, mengajak berkomunikasi, dan mengajarkan kegiatan sehari-hari. Aspek ketiga yaitu memenuhi kebutuhan fisik maupun psikis. Kebutuhan fisik dan psikis dapat diwujudkan dalam hal mampu memenuhi kebutuhan seharihari, mendampingi dalam berbagai kegiatan, memberikan cinta kasih, semangat, bimbingan, dan motivasi untuk anak. Menurut Arifin dalam (Umar, 2015) peran orang tua selain mendidik dan mebimbing adalah sebagai motivator dan fasilitator. Orang tua memiliki semangat untuk merawat anaknya yang berkebutuhan khusus dan berusaha menjadikannya mandiri. Kebutuhan sehari-hari seperti membantu makan dan memakai baju udah menjadi rutinitas orang tua dalam mendampingi anaknya sebagai perannya sebagai fasilitator. Dukungan psikis seperti pemberian semangat, motivasi untuk bersekolah agar lebih mandiri dan semangat sembuh dari sakit juga diberikan oleh orang tua merupakan peran orang tua sebagai motivator.

Aspek keempat adalah menjalin komunikasi secara baik dan bijak. Setiap anak berkebutuhan khusus memerlukan bantuan yang berbeda-beda. Tetapi, hal utama yang harus dikuasai terlebih dahulu adalah belajar bagaimana berkomunikasi. Kesulitan berbicara yang dialami oleh ABK membuat orang tua juga mengupayakan untuk mengikuti program terapi wicara. Aspek kelima tidak membedakan dan membandingkan dengan anak lain. Sikap penerimaan diri ditunjukkan oleh sikap pengakuan seseorang terhadap kelebihankelebihannya sekaligus menerima kelemahankelemahannya tanpa menyalahkan orang lain dan memiliki keinginan untuk terus mengembangkan diri (Faradina, 2016). Orang tua menyadari bahwa disabilitas yang dialami anak nya tidak hanya terfokus pada satu jenis disabilitas. Selain tunarungu, tunanetra, dan gangguan perilaku, mereka juga mempunyai perkembangan pola pikir yang lambat tidak seperti teman sebaya nya. Hal yang dilakukan orang tua adalah memahami kemampuan yang dimiliki anak dengan dukungan atau moivasi dari guru agar lebih bersabar dalam mendampingi belajar.

Aspek keenam memberikan bimbingan, semangat, motivasi. Dukungan yang diberikan ketiga subjek kepada anaknya bahwa mereka memberikan bimbingan untuk mengerjakan kegiatan sehari-hari, dan memotivasi untuk lebih sehat serta lebih semangat belajar agar kelak menjadi anak yang mandiri. Aspek ketujuh adalah menjadi teladan bagi anak dengan cara berkelakuan baik. Anak-anak dalam keseharian belajar meniru orang dewasa yang berada di sekitarnya. Seperti yang disampaikan Hulock (1978) belajar dengan cara meniru (learning by imitation) dapat sekaligus mempengaruhi aspek rangsangan dan aspek reaksi. Agar bisa menjadi teladan yang baik bagi anak orang tua selalu mengutamakan kebutuhan anak, memberikan contoh-contoh sikap yang baik seperti berucap yang baik, lalu menemani kegiatan anak, dan sebisa mungkin tidak melakukan hal-hal yang dilarang dilakukan oleh anak. Sehingga yang dilakukan anak sesuai dengan yang diharapkan yaitu berkelakuan baik.

Aspek terakhir yang kedelapan yaitu tidak menuntut atau memaksakan kehendak anak. Menurut Rogers dalam (Pancawati, 2013) penerimaan diri merupakan sikap seseorang yang menerima orang lain apa adanya secara keseluruhan, tanpa disertai persyaratan ataupun penilaian. Akseptabilitas orang tua tterwujud pada tidak menargetkan kemampuan anak sesuai dengan umur nya. Pokok utama harapan orang tua adalah anak bisa mandiri dan dapat berkomunikasi dengan cara memberikan kesempatan belajar bagi anak baik di sekolah atau melalui kegiatan terapi. Apabila 
perkembangan belum sesuai yang diharapkan, ketiga orang tua ini tetap sabar untuk mendampingi setiap tahap perkembangan anak nya.

\section{Faktor-faktor Akseptabilitas Orang Tua}

Aspek-aspek akseptabilitas (penerimaan) diri orang tua tidak lepas dari faktor-faktor yang mempengaruhi. Faktor-faktor ini merupakan sebuah alasan orang tua menerima anaknya yang berkebutuhan khusus. Menurut Hurlock dalam (Pancawati, 2013) menjelaskan faktor-faktor tersebut dipengaruhi oleh:

\section{a. Konsep Anak Idaman}

Orang tua yang mempunyai konsep sangat romantis mengenai calon anak, hal ini mungkin menimbulkan rasa kecewa dan tidak senang bila anak itu tidak sesuai dengan konsep tersebut (Hurlock, 1978). Ada orang tua yang mengungkapkan bahwa anak idaman adalah anak-anak yang normal pada umumnya, sehat, dan panjang umur. Kelahiran anak yang memiliki kebutuhan khusus bukanlan idaman mereka. Akan tetapi, mereka tetap menerima keadaan anaknya.

\section{b. Pengalaman awal dengan anak mewarnai sikap orang tua terhadap anaknya}

Memiliki anak berkebutuhan khusus merupakan pengalaman pertama bagi ketiga subjek. Orang tua yang memiliki anak berkebutuhan khusus dapat mengetahui istilahistilah dalam kebutuhan khusus serta mendapatkan pengalaman untuk merawat anak berkebutuhan khusus. Hal ini menunjukkan adanya perspektif yang luas pada diri orang tua. Menurut Hurlock dalam (Selvi, 2017) perspektif diri yang luas adalah memperhatikan pandangan orang lain mengenai kebuhutah khusus yang dialami oleh anaknya. Perspektif diri yang luas ini diperoleh dari pengalaman dan belajar sehingga orang tua dapat menyikapi anak yang berkebutuhan khusus dengan baik.

\section{c. Nilai Budaya}

Nilai budaya pada penelitian ini berkaitan dengan faktor yang mendukung akseptabilitas atau penerimaan orang tua yang memiliki anak berkebutuhan khusus diantaranya adalah pandangan masyarakat dan keikutsertaan orang tua dalam komunitas. Interaksi yang dilakukan oleh orang tua yang memiliki anak berkebutuhan khusus tidak terbatas pada lingkungan sekitar, akantetapi ada sebuah komunitas yang menjadi wadah bertemunya para orang tua yang memiliki anak berkebutuhan khusus. Ketiga subjek masing-masing mengikuti perkumpulan orang tua ada yang di tingkat kecamatan, di sekolah, maupun yang terikat dengan dinas sosial. Komunitas yang diikuti oleh ketiga subjek yaitu Federasi Komunikasi Keluarga Penyandang Disabilitas (FKKPD). Menurut Malecki dan Dermaray dalam (Hidayati, 2011:13) salah satu faktor ketahanan keluarga yang memiliki ABK adalah adanya dukungan sosial dari teman atau teman, dan komunitas. Dukungan sosial bisa meliputi dukungan emosional, informasi, atau materi guna untuk meningkatkan kemampuan diri untuk bertahan. Hal tersebut dirasakan orang tua ketika tergabung dalam FKKPD karena memalui lembaga komunitas tersebut orang tua diberikan bantuan berupa uang untuk kebutuhan anaknya yang berkebutuhan khusus, pelatihan pemberdayaan orang tua sekaligus modal usaha, materi penyuluhan tentang kasih sayang pada anak dan cara mendidik anak, dan saling berbagi cerita sesame orang tua yang memiliki ABK.

d. Orang tua yang menyukai peran, merasa bahagia, dan mempunyai penerimaan yang baik terhadap perkawinan, akan mencerminkan penerimaan yang baik pada anak.

Menurut Rogers dalam (Pancawati, 2013) penerimaan diri merupakan sikap seseorang yang menerima orang lain apa adanya secara keseluruhan, tanpa disertai persyaratan ataupun penilaian. Ketiga subjek telah sampai pada taham acceptance, salah satu faktor yang sangat berpengaruh adalah menyukai peran sebagai orang tua dan merasa bahagia memiliki ABK. Orang tua sudah merasa bahagia dan berusaha ikhlas memiliki ABK dengan memberikan yang terbaik bagi anak walaupun sempat terbesit rasa iri melihat orang tua lain bisa bekerja dan berpenghasilan sendiri. Kini, anak menjadi prioritas utama dalam keluarga agar bisa terpenuhi kegiatannya sehari-hari dan terpenuhi hak nya untuk sekolah.

\section{e. Apabila orang tua merasa mampu berperan sebagai orang tua, sikap mereka terhadap anak dan perilakunya lebih baik dibandingkan sikap mereka yang merasa kurang mampu dan ragu-ragu. \\ Pengaruh keberhasilan yang dialami,} keberhasilan yang dialami dapat menimbulkan penerimaan diri (yang positif). Sebaliknya, kegagalan yang dialami mengakibatkan adanya penolakan diri (Hurlock dalam Selvi, 2017). Indikator orang tua merasa mampu berperan sebagai orang tua yang memiliki ABK adalah tidak membeda-bedakan dengan anak lain dan lebih perhatian kepada ABK. Orang tua menyatakan bahwa tidak membeda-bedakan 
dengan anak lain. Sikap tidak peduli orang tua kandung $\mathrm{Gb}$ menunjukkan bahwa tidak adanya penerimaan dalam dirinya.

\section{f. Kemampuan dan kemauan untuk menyesuaikan diri}

Menurut Hurlock dalam (Selvi, 2017:73) Identifikasi dengan Orang yang Memiliki Penyesuaian Diri yang Baik Individu yang mengidentifikasi diri dengan orang yang dapat menyesuaikan dirinya dengan baik (well adjusted), dapat membangun sikap-sikap yang positif terhadap diri sendiri dan bertingkah laku dengan baik. Hal ini dapat menimbulkan penerimaan diri dan penilaian diri yang baik. Penyesuaian diri tidak lepas dari dukungan sosial, baik dari keluarga, kerabat, dan lingkungan sekitar. Pada awalnya orang tua membatasi diri untuk membaur di lingkungan sekitar, akantetapi sekarang berusaha untuk membaur, mengajak bermaian, dan melihat reaksi orang-orang yang berada di lingkungan sekitar. Respon yang diberikan tetangga sebagai lingkungan sekitar subjek biasa saja, dan memahami keadaan subjek.

\section{g. Alasan memiliki anak}

Menurut Hurlock (1978, 68) sebagian orang menginginkan banyak anak, yang lain hanya sedikit, atau sama sekali tidak. Itu menjadi sebuah alasan orang tua menerima kelahiran anaknya walaupun berkebutuhan khusus. Memiliki anak merupakan salah satu tujuan dalam sebuah perkawinan. Orang tua menyatakan alasan memiliki anak adalah untuk memiliki keturunan yang menjadi generasi penerus ayah dan ibunya serta mengukuhkan keluarga dan pandangan banyak anak banyak rezeki. Alasan lain yang diungkapkan oleh $\mathrm{Bu}$ Wh sebagai orang tua sambung $\mathrm{Gb}$ adalah merasa bahwa $\mathrm{Gb}$ sudah dianggap seperti anak sendiri walaupun orang tua kandung $\mathrm{Gb}$ tidak ada rasa terimakasih karena anaknya sudah dirawat.

\section{SIMPULAN}

Berdasarkan hasil penelitian dalam penelitian ini akseptabilitas atau keberterimaan merupakan puncak dari seluruh tahapan yang dimulai penolakan (denial) yang ditunjukkan dengan rasa kaget, marah (anger) terhadap diri sendiri dan Tuhan, tawar-menawar (bargaining) dengan memohon kepada Tuhan untuk kesembuhan anak, depresi (depression) karena meratapi keadaan anak dan tahap terakhir adalah penerimaan (acceptance), orang tua dan keluarga dapat menerima keadaan anak ditunjukkan dengan bersyukur terhadap kondisi anak, lebih menyayangi, bersungguh-sungguh merawat anak, serta mengupayakan kesembuhan anak. Ada satu orang tua yang tidak menerima kondisi anak, sehingga anak diasuh oleh saudara dari ibu anak tersebut. Aspek-aspek akseptabilitas merupakan sikap positif orang tua yang menerima kondisi ABK ditunjukkan dengan selalu berpartisipasi dalam kegiatan anak, memikirkan dan berusaha untuk meningkatkan perkembangan anak dengan memberikan hak pendidikan dan mengikutkan program terapi, memenuhi kebutuhan fisik dan psikis, menjalin komunikasi secara baik dan bijak, tidak membedakan dan membandingkan dengan anak lain, memberikan bimbingan, semangat, dan motivasi, menjadi teladan yang baik bagi anak dengan cara berkelakuan baik, serta tidak menuntut atau memaksakan kehendak anak. Orang tua dapat melalui tahapan akseptabilitas dan menunjukkan sikap positif terhadap anak didukung oleh faktor-faktor akseptabilitas yaitu menyukai peran dan mampu berperan sebagai orang tua yang memiliki ABK, mendapatkan dukungan keluarga, dukungan sosial dari komunitas, mampu menyesuaikan diri dengan lingkungan dan memiliki alasan utama memiliki anak yaitu sebagai generasi penerus keluarga.

\section{DAFTAR PUSTAKA}

Ardianti, S. D., Wanabuliandari, S., \& Wijayanti, E. (2021). Need Analysis of "Si Eco" Ethno-Confidence Game for Slow Learner Students. Jurnal Ilmiah Sekolah Dasar, $5(3)$.

Deviana, G dan Handayani, P. 2016. Gambaran Proses Penerimaan Diri Ibu yang Memiliki Anak Disleksia. Jakarta : Indonesian Journal Of Disability, Vol. 3, No. 1, 44-52.

Dolu Edwardus R. Y, Beatriks N. B, dan Indra, Y. K. 2014. Gambaran Penerimaan Orang Tua Anak Usia Dini Berkebutuhan Khusus Nusa Tenggara Timur. Nusa Tenggara Timur : Jurnal Pendidikan Teknologi dan Vokasi, Vol. 13. No 2, 45-49.

Faradina, Novira. 2016. Penerimaan Orang tua yang Memiliki Anak Berkebutuhan Khusus. Kalimantan Timur : eJurnal Psikologi, Vol. 4. N0. 4, 386-396.

Hidayati, Nurul. 2011. Dukungan Sosial Bagi Anak Berkebutuhan Khusus. Gresik, Jawa Timur : Jurnal Insan, Vol. 13, No. 1, 12-20.

Hurlock, Elizabeth B. 1978. Perkembangan Anak. Jakarta : Erlangga. 
Erlita Normasari, Meita Fitrianawati, dan Nurul Hidayah Akseptabilitas Orang Tua Terhadap Anak Berkebutuhan Khusus di Kota ... WASIS: Jurnal Ilmiah Pendidikan. Volume 2 Nomor 2 Hlm. 133-139

Kubler-Ross, Elisabeth. 2009. On Death and Dying. London : Routledge.

Lubis, Namora Lumongga. 2016. DEPRESI Tinjauan Psikologi. Jakarta : PT Fajar Interpratama Mandiri.

Marlina. 2009. Asesmen Anak Berkebutuhan Khusus. Padang : Universitas Negeri Padang.

Maulipaksi, Desliana. 2017. Kemendikbud. [Online] Kementrian Pendidikan dan Kebudayaan, Februari 1, 2017. [diakses: 10 Januari 2019 Pukul 20.05.] http://www.kemendikbud.go.id/main/blog/2 017/02/mendikbud-imbau-orang-tua-aktifdaftarkan-anak-berkebutuhan-khusus-kesekolah.

Moktaningrum, Vera. 2014. Penerimaan Orang tua Terhadap Anak Berkebutuhan Khusus. Skripsi. Yogyakarta : Universitas Sanata Dharma, 2014.

Pancawati, Ririn. 2013. Intisari Penerimaan Diri dan Dukungan Orang tua Terhadap Anak Autis. Kalimantan Timur : Jurnal Psikologi, Vol. 1, No. 1, 38-47.

Ruskhan, Abdul Gaffar, et al. 2016. Kamus Besar Bahasa Indonesia Edisi Kelima. Jakarta : Badan Pengembangan dan Pembinaan Bahasa, Kementrian Pendidikan dan Kebudayaan Republik Indonesia.

Selvi dan Shanty. 2017. Gambaran Faktor yang Mempengaruhi Penerimaan Diri Orang tua Yang Memiliki Anak Autisme. Jakarta : Jurnal Psibernetika, Vol. 10, No. 2, 70-80.

Sugiyono. 2016. Metode Penelitian Pendidikan Pendekatan Kuantitatif, Kualitatif, dan $R \& D$. Bandung : Alfabeta.

Syarifudin, Ahmad. 2018. Tribun News. [Online] Agustus 3, 2018. [Diakses: 25 Januari 2019 pukul http://jogja.tribunnews.com/amp/2018/03/s eribu-anak-berkebutuhan-khusus-di-diybelum-dapat-hak-pendidikan.

Umar, Munirwan. 2015. Peran Orang Tua dalam Peningkatan Prestasi Belajar Anak., : Jurnal Ilmiah Edukasi, Vol. 1, No. 1, 20-28. 